\title{
PENGEMBANGAN BIBIT BUAH LOKAL UNGGUL WANI BALI TANPA BIJI
}

\author{
N.L.M. Pradnyawathi ${ }^{1}$, I.K. Sardiana ${ }^{2}$, dan N.N. Darmiati ${ }^{3}$
}

\begin{abstract}
ABSTRAK
Kegiatan pengabdian kepada masyarakat program pengembangan usaha produk intelektual kampus (PPUPIK) ini bertujuan : 1) komersialisasi Ipteks kreativitas kampus sebagai sumber pembiayaan untuk pengembangan institusi; 2) memacu jiwa kewirausahaan di kalangan insan kampus; dan 3) membantu masyarakat mendapatkan bibit wani local unggul tanpa biji. Pelaksanaan kegiatan terdiri dari tiga tahap yaitu : 1) Penyiapan sarana dan fasilitas PPUPIK terdiri dari kegiatan pengadaan batang bawah, pengadaaan batang atas (pohon induk), dan pembangunan kebun produksi, 2) Proses produksi Bibit Wani Bali Tanpa Biji terdiri dari penyemaian batang bawah, pengambilan batang atas (entrisj), penyambungan (grafting) dan pemeliharaan dan 3) Penjajagan pemasaran/promosi ke instansi pengguna yaitu Pemda Tabanan. Ditemukan ada 2 pohon wani tanpa biji Desa Blimbing, Kecamatan Pupuan, Tabanan yang dipakai sebagai batang atas. Sebagai batang bawah digunakan wani local. Bibit wani tanpa biji yang sudah dihasilkan adalah 300 batang bibit sambungan, dan 1.200 bibit batang bawah.
\end{abstract}

Kata kunci : produk intelektual kampus, bibit wani Bali unggul tanpa biji, grafting, entrisj

\begin{abstract}
Community service program for campus intellectual product development (PPUPIK) is aimed at: 1) commercialization of campus creativity science and technology as a source of funding for institutional development; 2) spur entrepreneurial spirit among campus people; and 3) help the community get Superior Local Fruit Seedless Wani Bali. The implementation of the activity consists of three stages, namely: 1) Preparation of PPUPIK facilities consisting of the procurement of rootstock, the provision of the top stem (entrisj), and the development of production plantations, 2) The production process of Seedless Wani Bali Seedlings consists of seeding the rootstock, taking the top stem (entrisj), grafting and maintenance and 3) Assessment of marketing / promotion to user agencies, namely the Government of Tabanan. There were found 2 seedless wani trees in Blimbing Village, Pupuan District, Tabanan, which were used as an entrisj. As a rootstock, local wani are used. Seedless Wani Bali seedlings that have been produced are 300 grafting seedlings, and 1,200 rootstock seedlings.
\end{abstract}

Keywords: campus intellectual products, seedless Wani Bali seedlings, grafting, entrisj

\section{PENDAHULUAN}

Walaupun Indonesia merupakan negara agraris dan mempunyai potensi yang sangat besar untuk menghasilkan beraneka jenis buah-buahan, sampai saat ini Indonesia masih harus mengimpor untuk memenuhi kebutuhan konsumsi buah dalam negeri. Semakin terpinggirkannya buah lokal antara lain disebabkan kurang tersedianya benih berkualitas dalam jumlah memadai, di samping perubahan perilaku konsumen yang semakin menyukai produk impor dan semakin mudah dan

\footnotetext{
${ }^{1}$ Program Studi Agroekoteknologi, Fakultas Pertanian, Universitas Udayana, pradnyawathi@unud.ac.id

${ }^{2}$ Program Studi Agroekoteknologi, Fakultas Pertanian, Universitas Udayana, ketutsardiana@unud.ac.id

${ }^{3}$ Program Studi Agroekoteknologi, Fakultas Pertanian, Universitas Udayana, darmiati@unud.ac.id
} 
murahnya impor buah-buahan. Adanya pergeseran buah lokal oleh buah impor tersebut menyebabkan terancamnya keberadaan sumberdaya genetik (plasma nutfah) buah-buahan lokal, yang berakibat pada semakin langkanya jenis-jenis buah-buahan lokal dan bahkan bisa menyebabkan kepunahan (Putri et al.,2017; Kusumawati et al, 2018). Selanjutnya dikatakan perlu dilakukan penyelamatan terhadap sumber daya genetik local (plasma nutfah) buah-buahan dengan cara melestarikan, mengamankan sekaligus memanfaatkan keanekaragaman genetika seoptimal mungkin sehingga berguna bagi generasi sekarang maupun yang akan datang yang diikuti dengan upaya pengembangan buah-buahan lokal secara holistic. Rohyani (2015), menyatakan buah-buhan local berpotensi tinggi menggantikan buah-buah impor di pasaran karena buah lokal memiliki bentuk dan cita rasa yang sangat khas.

Salah satu buah local bali yang sangat disukai adalah buah wani. Wani mempunyai citarasa yang enak, manis dan mempunyai aroma yang khas. Wani Bali (Mangifera caesia Jack.) merupakan salah satu tanaman buah-buahan tropika tergolong kerabat mangga. Dari hasil penelitian Rai (2008) ditemukan 22 jenis atau kultivar wani yang ada di Bali. Salah satu wani yang mempunyai nilai ekonomis yang tinggi dan berpotensi untuk dikembangkan secara komersial adalah wani tanpa biji (Wani Ngumpen Bali). Wani ngumpen mempunyai sifat yang sangat khas yaitu daging buahnya yang sangat tebal dan tidak memiliki biji. Rai et al., (2007), dan Rai et al. (2013) menyatakan wani tanpa biji (Mangifera caesia Jack. var. Ngumpen Bali) memiliki sifat has yang berbeda dengan kultivar lainnya di mana buahnya tidak berbiji, daging buah tebal sehingga edible portion nya atau bagian buah yang dapat dimakan sangat tinggi. Citarasa buahnya enak, manis tanpa rasa asam, dan aromanya menarik sehingga sangat disukai oleh konsumen. Dengan tidak adanya biji menyebabkan wani ini sulit untuk dikembangkan sehingga merupakan salah satu kendala dalam pengembangan wani tanpa biji ini. Mahardika et al. (2013) menyatakan bahwa hal-hal yang merupakan kendala dalam pengembangan Wani Bali tanpa biji adalah sulitnya memperoleh bibit, harga bibit yang mahal, dan pertumbuhan bibit yang sangat lambat.

Dalam perdagangan buahpun, Wani Bali belum diperhitungkan di samping karena kurangnya promosi juga karena keterbatasan volume produksi akibat populasinya yang sangat terbatas, disertai kurangnya minat masyarakat untuk mengembangkannya karena waktu berbuah yang lama, ini merupakan hal yang sangat mengkawatirkan sehingga perlu segera diambil langkah-langkah pelestarian dan pengembangannya. Salah satu sentra produksi Wani di Bali adalah Kecamatan Pupuan dan Kecamatan Selemadeg di Kabupaten Tabanan. Buah Wani Bali dihasilkan secara alami (di kebun, pekarangan, dan areal sekitar hutan) tanpa pemeliharaan secara memadai, sehingga kuantitas dan kualitas buahnya rendah. Di Kecamatan Pupuan ini juga ditemukan wani unggul yang tanpa biji (wani bali ngumpen) ini. Tanaman ini sangat mudah dikenali karena sifat spesifik buahnya tanpa biji, warna kulit buahnya hijau kekuningan mengkilap dengan ukuran buah seragam. Disebut Wani Bali Ngumpen atau Wani Bali tanpa biji karena 90\% jumlah buah tidak berbiji. Berdasarkan hasil pengamatan, buah-buah yang berbiji posisi tempat tumbuhnya selalu pada ujung tandan buah. Apabila bunga yang tumbuh pada ujung tandan tidak berhasil berkembang menjadi buah, maka seluruh buah pada tandan tersebut menghasilkan buah tanpa biji. Uniknya, bunga yang tumbuh pada ujung tandan sangat sedikit yang berhasil menjadi buah sehingga kultivar tersebut menghasilkan proporsi buah tanpa biji jauh lebih banyak dibandingkan dengan buah berbiji (Rai, 2008).

Kelangkaan tanaman wani terjadi karena tanaman wani tanpa biji tumbuh sendiri, bukan hasil budidaya atau penanaman. Usaha penanaman tanaman baru tidak memungkin karena buah tidak memiliki biji yang biasa dilakukan masyarakat untuk perbanyakan tanaman. Sementara itu, perbanyakan dengan cara lainnya belum dikuasai oleh masyarakat. Akibatnya, populasi wani tanpa biji semakin menyusut karena tidak ada regenerasi. Oleh sebab itu, untuk menjaga populasi Wani Tanpa Biji dan pelestarian plasma nuftah unggul tersebut maka sangat diperlukan usaha 
pembibitan dengan aplikasi teknologi yang mampu menghasilkan tanaman hasil perbanyakan secara vegetatif.

Pemerintah Kabupaten Tabanan, dalam pengembangan pertanian di Kecamatan Pupuan Kabupaten Tabanan telah membangun taman teknologi pertanian (TTP). Taman teknologi pertanian ini diharapan akan menjadi pusat edukasi inovasi dalam bidang pertanian dari hulu ke hilir yang terintegrasi pariwisata. Salah satu daya tarik yang ditawarkan adalah agrowisata buah-buahan lokal unggul, salah satu diantaranya adalah wani tanpa biji. Hal ini perlu didukung oleh penyediaan bibit yang memadai sehingga pengembangan wani tanpa biji dapat diperluas.

\section{METODE PELAKSANAAN}

Urut-urutan Kegiatan PPUPIK Bibit Buah Lokal Unggul Wani Bali Tanpa Biji adalah eksplorasi pohon induk, penentuan kebun produksi yang terdiri dari balai seedling dan nursery, proses produksi dan pemasaran. Proses produksi dimulai dari persiapan batang bawah, persiapan entrisj (batang atas), penyambungan (grafting) dan pemeliharaan bibit.

\section{HASIL DAN PEMBAHASAN}

Karya utama dari pengabdian ini adalah pembibitan wani tanpa biji. Dalam pembibitan ini dilakukan pembuatan bibit secara vegetative dengan penerapan teknik top grafting atau sambung pucuk. Keistimewaan cara vegetative dengan teknik top grafting ini adalah tanaman akan memberikan hasil yang sama dengan induknya dan akan berbuah lebih cepat dibandingkan dengan perbanyakan dari biji. Salah satu cara pembiakan vegetative adalah sambung pucuk (top grafting). Adapun kelebihan dari cara vegetative dibandingkan dengan cara generative (dari biji) adalah : (1) umur berbuah lebih cepat. (2) Aroma dan cita rasa buah tidak menyimpang dari sifat induknya. (3) diperoleh individu baru dengan sifat unggul lebih banyak, misalnya batang bawah (rootstock) yang unggul perakarannya disambung dengan batang atas (entris, scion) yang unggul produksi buahnya.

Proses produksi Bibit Wani Bali Unggul Tanpa Biji dimulai dari penyiapan batang bawah dan batang atas (entrisj). Untuk batang bawah, biji yang dipakai diambil dari wani local. Biji dari wani local disemai di dalam polybag yang sudah diisi dengan media tanam. Untuk media tanam dipakai tanah dan mikoriza. Untuk entrisj dipakai pucuk wani tanpa biji. Dari hasil survey di Desa Belimbing, Kecamatan Pupuan, Kabupaten Tabanan ditemukan ada 2 pohon wani tanpa biji. Pohon pertama ada di Br. Duren Taluh, Desa Belimbing (Gambar 1) dan pohon kedua ditemukan di Br. Blimbing Anyar, Desa Blimbing (Gambar 2). 


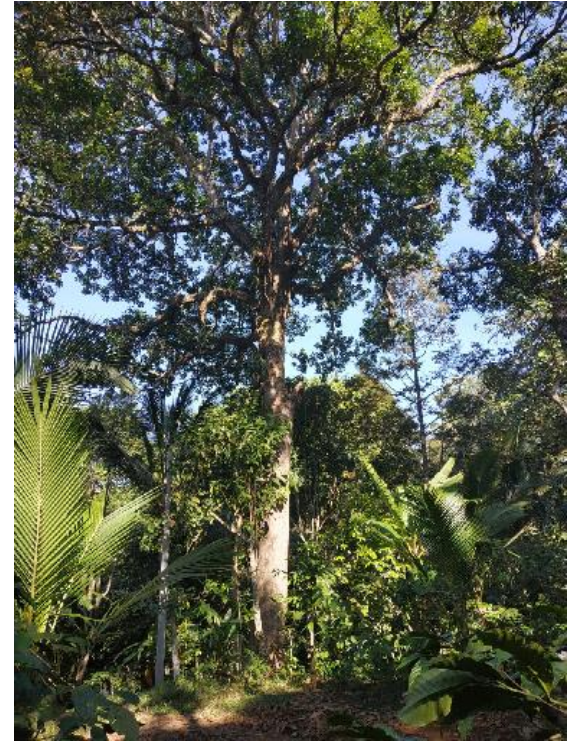

Gambar 1. Pohon induk wani tanpa biji di Br. Duren Taluh, Desa Belimbing

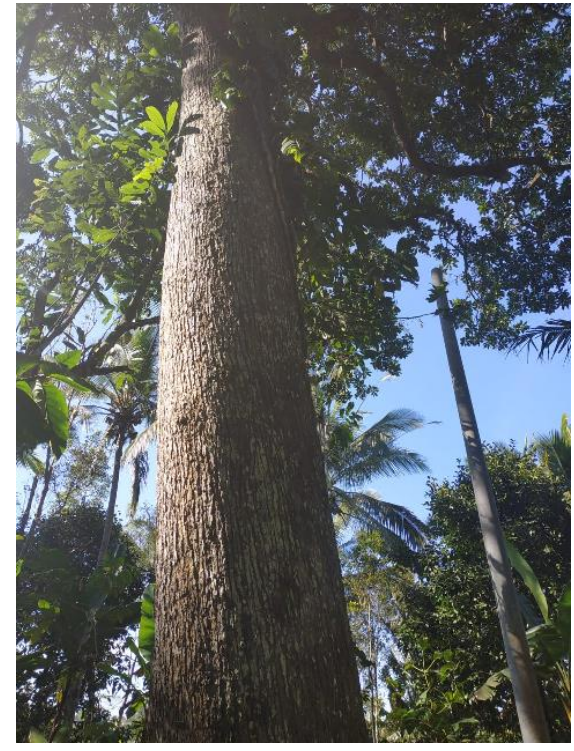

Gambar 1. Pohon induk wani tanpa biji di Br. Blimbing Anyar, Desa Belimbing

Pelaksanaan grafting atau penyambungan dimulai dengan pemilihan batang bawah dan penyiapan entrisj. Batang bawah dipilih bibit yang tumbuh sehat dan gigas. Batang bawah sudah berumur lebih dari 6 bulan (Gambar 3).

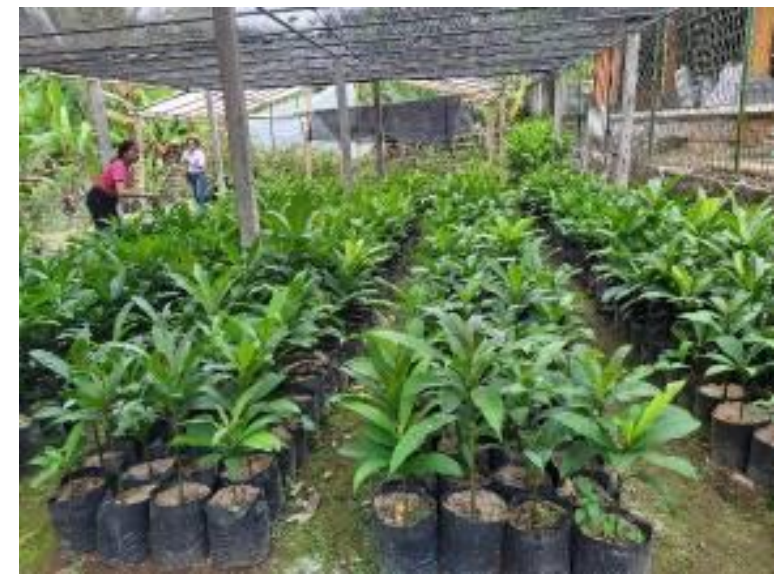

Gambar 3. Batang bawah berumur 6 bulan

Untuk persiapan batang atas (entrisj) dipilih pucuk-pucuk wani yang sehat, kemudian dibungkus pelepah pisang supaya entrisj tidak cepat mengering. Adapun cara penyambungannya adalah batang bawah dipotong pada ketinggian sekitar $20 \mathrm{~cm}$. bekas potongan kemudian dibelah sedalam $2 \mathrm{~cm}$, entrisj atau batang atas dengan panjang sekitar $8 \mathrm{~cm}$ dihilangkan daunnya, bagian bawahnya dibuat meruncing kemudian diselipkan ke dalam belahan batang bawah. Sambungan kemudian diisolasi/dililit dengan plastic okulasi yang sudah direntangkan. Sambungan disungkup dengan plastic dan diikat bagian bawahnya untuk mengurangi penguapan. Bibit kemudian ditempatkan di balai nursery supaya terhindar dari matahari langsung.

Setelah Kegiatan grafting maka dilakukan pemeliharaan bibit. Kegiatan pemeliharaan terdiri dari penyiraman, pemupukan dan pengendalian OPT. Bibit dijaga kelembabannya dengan menyiramnya 
setiap sore. Sambungan yang berhasil ditandai dengan batang atas yang masih tetap hijau. Plastic okulasi bisa dibuka setelah 3 minggu dari waktu penyambungan. Bibit siap tanam setelah 3 bulan dari waktu penyambungan (Gambar 4).

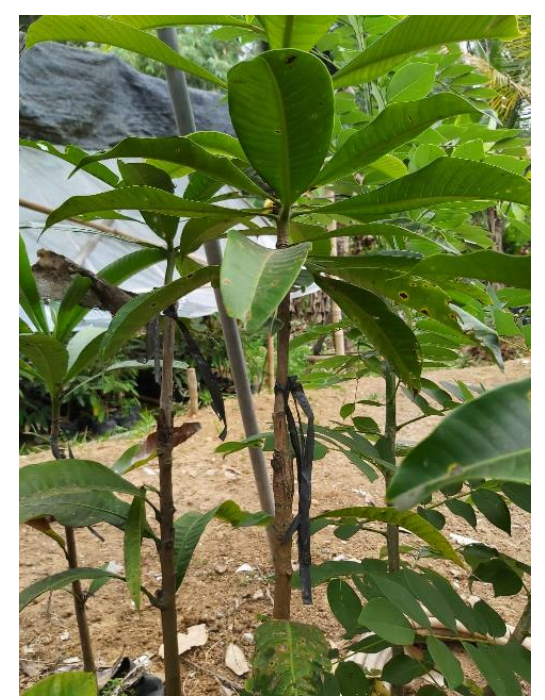

Gambar 4. Bibit siap jual

Sampai saat ini grafting yang sudah berhasil ada 300 tanaman. Kegiatan ini direncanakan akan berlangsung selama 3 tahun, dengan target tahun pertama 500 bibit, tahun kedua 1000 bibit dan tahun ketiga 2000 bibit.

Produksi tahun petama terbatas untuk ditanam di areal Agroteknopark (Taman Teknologi Pertanian/TTP) dan kebun-kebun masyarakat disekitar areal Agroteknopark di Desa Sanda, Kecamatan Pupuan, Tabanan kerjasama dengan Pemerintah abupaten Tabanan. Pengembangan di kebun masyarakat dimaksudkan untuk pengembangan agrowisata berbasis masyarakat sehingga masyarakat sebagai penyedia jasa/produk bagi wisatawan (Sardiana and Purnawan, 2016)

\section{KESIMPULAN}

Kesimpulan yang dapat diambil dari pelaksanaan kegiatan PPUPIK Pembibitan Wani Tanpa Biji Tahun 2019 adalah sebagai berikut:

1. Pelaksanaan kegiatan terdiri dari tiga tahap yaitu (a) Penyiapan sarana dan fasilitas PPUPIK terdiri dari kegiatan pengadaan batang bawah, pengadaaan batang atas (pohon induk), dan pembangunan kebun produksi, (b) Proses produksi Bibit Wani Bali Tanpa Biji terdiri dari penyemaian batang bawah, pengambilan batang atas(entrisj), penyambungan (grafting) dan pemeliharaan, (c) Penjajagan pemasaran/promosi ke instansi pengguna yaitu Pemda Tabanan.

2. Ditemukan ada 2 pohon wani tanpa biji Desa Blimbing, Kecamatan Pupuan, Tabanan. Pohon pertama ada di Br. Duren Taluh, Desa Belimbing dan pohon kedua ditemukan di Br. Blimbing Anyar, Desa Blimbing.

3. Bibit wani tanpa biji yang sudah dihasilkan adalah 300 batang bibit sambungan, dan jumlah batang bawah adalah 1200 bibit

\section{UCAPAN TERIMA KASIH}

Ucapan terima kasih disampaikan kepada KEMENRISTEK DIKTI atas dana yang diberikan melalui program pengembangan usaha produk intelektual kampus (PPUPIK), Rektor Universitas Udayana, Ketua LPPM 
beserta staf serta staf lapangan sehingga pengabdian kepada masyarakat terlaksana dengan baik dan sesuai rencana.

\section{DAFTAR PUSTAKA}

Kusumawati, A., N. E. Putri, N. O. Azhar, dan E. Swasti. (2018). Karakterisasi Plasma Nutfah Buah Lokal di Kabupaten Lima Puluh Kota dan Kota Solok. Jurnal Agrosains dan Teknologi 3 (1) : 19 - 29

Mahardika, I K.D., I N. Rai, dan I W. Wiratmaja. (2013). Pengaruh Komposisi Campuran Bahan Media Tanam Dan Konsentrasi IBA Terhadap Pertumbuhan Bibit Wani Ngumpen Bali (Mangifera Caesia Jack). E-Jurnal Agroekoteknologi Tropika 2 (2) : 126-134.

Rohyani, I.S., E. Aryanti, Suripto. (2015). Potensi Nilai Gizi Tumbuhan Pangan Lokal Pulau Lombok sebagai Basis Penguatan Ketahanan Pangan Nasional. Pros Sem Nas Masy Biodiv Indon. 1 (7) : 16981701.

Rai, I.N., G. Wijana, dan C. G. A. Semarajaya. (2008). Identifikasi Variabilitas Genetik Wani Bali (Mangifera caesia Jack.) dengan Analisis Penanda RAPD. J. Hort. 18(2):125-134.

Putri, N.E., A Kusumawati, N.O. Azhar, dan E. Swasti. (2017). Eksplorasi dan Karakterisasi Buah-buah Lokal Sumatera Barat yang Terancam Punah. Pros Sem Nas Masy Biodiv Indon. 3 (1) : 117-126.

Rai I. N., C.G.A Semarajaya, I.W. Wiraatmaja, dan N. K. A Astiari. (2013). Respon Pertumbuhan Bibit Wani Tanpa Biji (Mangifera caesia Jack var. Ngumpen Bali) pada Berbagai Komposisi Media Tumbuh. J. Hort. Indonesia 4(2):77-82.

Sardiana, IK., NLR Purnawan., 2016. Indigenous community, ecotourism and sustainability: Experience from Tenganan Dauh Tukad traditional. Heritage, Culture and Society: Research agenda and best practices in the hospitality and tourism ind | vol: | issue : | 2016-01-01 | Conference Proceedin

Sardiana, IK., BRT Putri, IG Suranjaya, NLR Purnawan. 2015. Pengembangan Kewirausahaan di Universitas Udayana. Ngayah: Majalah Aplikasi IPTEKS 6 (1)

Tambing, Y., dan A. Hadid. (2008). Keberhasilan Pertautan Sambung Pucuk pada Mangga dengan Waktu Penyambungan dan Panjang Entris Berbeda. J. Agroland 15 (4) : 296 - 301. 